\title{
Analysis of Compressed Air Energy Conversion Processes in a Rotary Piston Pneumatic Engine
}

\author{
Mytrofanov O., Proskurin A. \\ Admiral Makarov National University of Shipbuilding \\ Mykolaiv, Ukraine
}

\begin{abstract}
This article describes a rotary piston pneumatic engine with a gas exchange system design that minimizes the value of the relative dead volume, as well as ensures the minimum dimensions and weight of the engine. The main purpose of the study is to evaluate the conversion efficiency of compressed air energy in the working cylinder of the rotary piston pneumatic engines using the exergy method of thermodynamic analysis. To achieve the set goal of the study, physical modeling of various operation modes has been performed. The most significant result is that, based on the physical and mathematical modeling, a thermodynamic assessment of the efficiency of the compressed air energy conversion has been performed. The significance of the results obtained lies in the fact that the effect of the main operational parameters of the pneumatic engine on the efficiency of energy conversion is established. The basic equations of the exergy method of the thermodynamic analysis are presented. The results of physical and mathematical modeling of various operation modes are presented. The main reasons for the decrease in the energy conversion efficiency at low and rated loads are emphasized. The amount of exergy supplied with the air flow was established, which, depending on the operation mode, amounted to $2.2 \ldots 11.4 \mathrm{~kW}$. According to the presented results, the most optimal speed range, based on the achievement of the maximum values of the specific efficient work and exergy efficiency, is $55 . .70 \%$ of the nominal value. It was found that an increase in the operation pressure decreases slightly the exergy efficiency. A twofold increase in the operation pressure of the pneumatic engine increases the efficient power by $46 \%$ at a simultaneous decrease in the exergy efficiency by $8.2 \%$.
\end{abstract}

Keywords: compressed air, rotary piston engine, power plant, exergy, anergy, thermodynamic analysis.

DOI: https://doi.org/10.52254/1857-0070.2021.1-49.03

UDC: 621.438

Analiza proceselor de conversie a energiei aerului comprimat într-un motor pneumatic cu piston rotativ Mitrofanov A.S., Proskurin A. Iu.

Universitatea Naţională de Construcții Navale amiralul Makarov

Nikolaev, Ucraina

Rezumat. În acest articol se investigează un motor de aer cu piston rotativ cu un sistem de schimb de gaze care minimizează ca valoarea volumului mort relativ, precum și contribuie la asigurarea dimensiunii şi greutății minime a motorului. Scopul principal al studiului este de a evalua eficiența conversiei energiei aerului comprimat în cilindrul de lucru al unui motor pneumatic cu piston rotativ prin metoda exergică a analizei termodinamice. Pentru a realiza obiectivul stabilit al studiului, a fost realizată modelarea fizică a diferitelor moduri de funcționare ale motorului pneumatic cu piston rotativ. Cel mai important rezultat este că, pe baza rezultatelor modelării fizice prin metoda modelării matematice, a fost efectuată o evaluare termodinamică a eficienței transformării energiei aerului comprimat într-un motor pneumatic cu piston rotativ. Semnificația rezultatelor obținute constă în faptul că s-a stabilit influența principalilor parametri operaționali ai unui motor pneumatic cu piston rotativ asupra eficienței conversiei energiei. Sunt prezentate ecuațiile de bază ale metodei exergice a analizei termodinamice. Sunt prezentate rezultatele modelării fizice și matematice a diferitelor moduri de funcționare ale unui motor pneumatic cu piston rotativ. Sunt evidențiate principalele motive pentru scăderea eficienței conversiei energiei la sarcini reduse și nominale ale motorului pneumatic. Cantitatea de energie furnizată odată cu fluxul de aer comprimat este determinată în funcție de modul de funcționare. Conform rezultatelor cercetării prezentate, cea mai optimă gamă de rotații ale unui motor cu aer cu piston rotativ, bazată pe realizarea valorilor maxime ale muncii eficiente specifice și eficienței exergice, este de $55 . . .70 \%$ din valoarea nominală. S-a constatat că o creștere a presiunii de funcționare a unui motor pneumatic cu piston rotativ duce la o uşoară scădere a eficienței exergice. O creștere de două ori a presiunii de funcționare în receptorul de admisie al unui motor cu aer cu piston rotativ contribuie la o creștere a puterii efective cu $46 \%$, reducând în acelaşi timp eficiența energetică cu $8,2 \%$. Rezultatele cercetării prezentate pot fi utilizate în proiectarea și construcția de noi eșantioane de motoare pneumatice cu piston rotativ în diverse scopuri. 
Cuvinte-cheie: aer comprimat, motor pneumatic cu piston rotativ, centrală electrică, energie, analiză termodinamică.

\section{Анализ процессов преобразования энергии сжатого воздуха в роторно-поршневом пневмодвигателе \\ Митрофанов А. С., Проскурин А. Ю.}

Национальный университет кораблестроения имени адмирала Макарова Николаев, Украина

Аннотация. В данной статье рассмотрен роторно-поршневой пневмодвигатель с конструкцией системы газообмена позволяющей минимизировать значение относительного мертвого объема, а также способствующей обеспечению минимальных габаритов и массы двигателя. Основной целью исследования является оценка эффективности преобразования энергии сжатого воздуха в рабочем цилиндре роторно-поршневого пневмодвигателя эксергетическим методом термодинамического анализа. Для достижения поставленной цели исследования выполнено физическое моделирование различных эксплуатационных режимов работы роторно-поршневого пневмодвигателя. Наиболее существенным результатом является то, что на основе результатов физического моделирования методом математического моделирования выполнена термодинамическая оценка эффективности преобразования энергии сжатого воздуха в роторно-поршневом пневмодвигателе. Значимость полученных результатов состоит в том, что установлено влияние основных эксплуатационных параметров роторно-поршневого пневмодвигателя на эффективность энергопреобразования. Приведены основные уравнения эксергетического метода термодинамического анализа. Представлены результаты физического и математического моделирования различных режимов работы роторно-поршневого пневмодвигателя. Выделены основные причины снижения эффективности энергопреобразования на режимах малых и номинальных нагрузок пневмодвигателя. Установлено количество подводимой с потоком сжатого воздуха эксергии в зависимости от эксплуатационного режима. Согласно представленным результатам исследования наиболее оптимальным диапазоном оборотов роторно-поршневого пневмодвигателя, исходя из достижения максимальных значений удельной эффективной работы и эксергетического КПД, является $55 \ldots 70$ \% от номинального значения. Установлено, что повышение рабочего давления роторнопоршневого пневмодвигателя приводит к незначительному снижению эксергетического КПД. Увеличение рабочего давления во впускном ресивере роторно-поршневого пневмодвигателя в два раза способствует увеличению эффективной мощности на $46 \%$ при одновременном снижении эксергетического КПД на 8,2 \%. Представленные результаты исследований могут использоваться при проектировании и конструировании новых образцов роторно-поршневых пневмодвигателей разного назначения.

Ключевые слова: сжатый воздух, роторно-поршневой пневмодвигатель, энергетическая установка, эксергия, анергия, термодинамический анализ.

\section{INTRODUCTION}

A fairly new and promising type of a pneumatic engine is a rotary piston pneumatic engine with equally-spaced radial cylinders. Its design combined the advantages and peculiarities of operation of piston and rotary pneumatic engines. The general construction of the rotary piston pneumatic engine with a working volume of $320.6 \mathrm{~cm}^{3}$ is shown in Fig. 1 .

The pneumatic engine has 12 pairwise opposite 44-mm diameter working cylinders mounted in the central rotor with a piston speed of $17.5 \mathrm{~mm}$. This is a short stroke engine, since the ratio of the piston travel to the cylinder diameter is 0.4 . The latter allows the compressed air pressure losses on the inlet and the backpressure of the spent air on the outlet to be decreased.

The central rotor serves also as the valve, controlling the gas exchange by opening and closing the gas exchange elements (inlet and outlet holes). This gas exchange construction minimizes the value of the relative dead volume to 0.015 . It ensures as well the engine minimal sizes and weight.

The pneumatic engine can regulate the degree of filling the working cylinder owing to the camshaft rotation. The camshaft also ensures the pneumatic engine reversing without impairing the operational parameters. The detailed description of the device and the pneumatic engine operational principle, as well as of the device experimental variant are presented in patent UA120489.

One major requirement in creation of novel highly efficient engines is to ensure a maximum thermodynamic accomplishment, i.e., to achieve a maximum efficiency coefficient. Thus, to estimate a new technical system (TS) the universally accepted methods of material, thermal and exergy balances are used. The most extensively used for the analysis of the energy 
conversion in the TS is in particular the method for thermal balances based on the first law of thermodynamics. However, the estimation of the energy efficiency using the thermal balance method is not always sufficient to reveal all the energy conversion peculiarities to the full extent. Very often a thermodynamic system appears to be a kind of a 'black box', and interaction and conversion of various forms of energy inside it remain obscure (e.g., the Sankey band diagram of the energy flow).

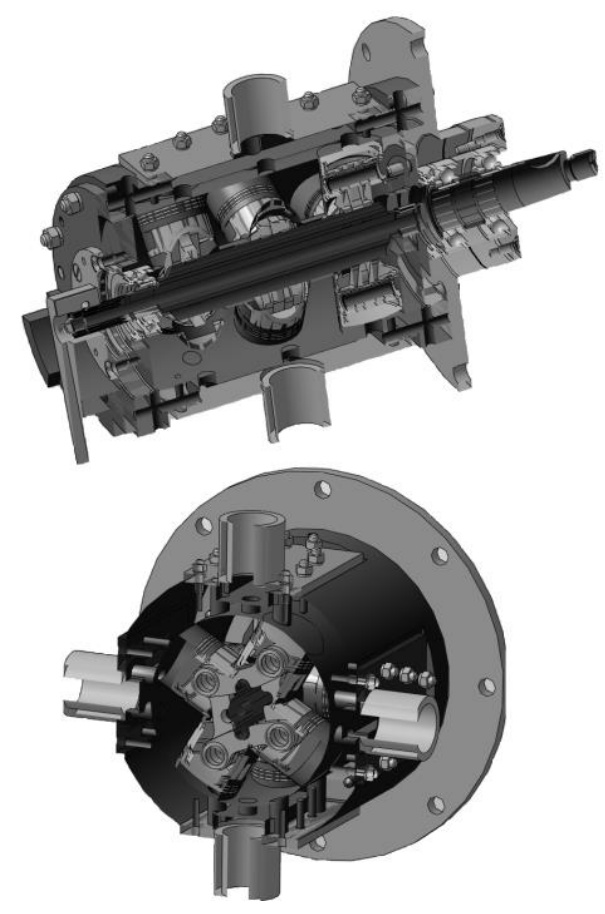

Fig. 1. Rotary piston pneumatic engine design

The exergy method of the thermodynamic analysis considers both the first and the second laws of thermodynamics.

In accordance to the second law of thermodynamics, the energy of two kinds is used in real energy conversion processes:

- the energy, which entirely turns into another form of energy, regardless of environmental parameters (exergy);

- and the energy, which cannot be converted owing to its properties or the environmental parameters (anergy).

Respectively, inlet and outlet from the TS energy flows can be represented as the exergy and anergy

flows, which allows us to obtain a more informative picture of the energy flows' usefulness (the Grossman diagram). Thus, the exergy characterizes energy not only quantitatively, but also makes it possible to estimate it quantitatively from the qualitative viewpoint.

The TS technical thermodynamic analysis using the exergy method allows obtaining information in order to perform thermodynamic (determination of the most rational modes and parameters of the TS operation, and at a design stage makes it possible to introduce changes into the elements of equipment or the TS structure) and technical-economic optimization.

The problem of analysis of the technical system using the exergy method amounts to determination of the values of the exergies of different kinds of energy, to formation the exergy balances of the system and its elements, to definition the exergy efficiency and losses. All these make it possible to determine the ways of further development of the technical system and its elements.

The basic theoretical principles of application of the exergy method in the thermodynamic analysis and optimization for various branches of engineering, the methods of formation the exergy balances and determination of the efficiency were fairly well described in [1-7].

The exergy method of the thermodynamic analysis was used extensively in different branches of industry and energetics. Thus, e.g., this method is utilized for the solar thermal systems [8-12] and storage systems of thermal energy of a centralized heat supply [13-14]. This thermodynamic analysis method is extensively used for the analysis of the energy conversion efficiency in different heat engines. Thus, [1519] describe combustion engines with an arc ignition, [20-25] deal with diesel engines, and [26-28] discuss gas turbines. In addition to the efficiency estimation of the fuel energy conversion in heat engines, the exergy method can be applied to analyze refrigerating systems [29] and, it can be used for the comparative analysis of various power installations [30-32].

The exergy method for the thermodynamic analysis is used to analyze the efficiency of compressors' operation, a cryogenic gas expansion machine, and pneumatic engines of various designs [33-36]. Thus, e.g., in [37], the exergy method was used to analyze the distribution of the energy losses in a piston pneumatic engine, and [38] describes the energy conversion efficiency in a rotary pneumatic engine.

The existing publications practically lack the analysis of a possible application of the exergy method of a thermodynamic analysis for the 
aforementioned type of pneumatic engines. Concerning the available recommendations, the latter can be used just in the first approximation in case of the efficiency estimation.

Our work differs from those western in that it offers to use the exergy method of the thermodynamic analysis for the estimation of the energy conversion efficiency in the rotary piston pneumatic engines of a new design. This will make it possible to estimate the exergy efficiency of the pneumatic engine, as well as to determine the distribution of the energy losses for the purpose of their minimization. Thus, the exergy efficiency affords to qualitatively estimate the amount of the TS useful energy per a unit of the consumed energy under the preset conditions, and it also enables to compare the energy efficiency of similar TS, which operate in identical conditions.

The exergy approach in the efficiency estimation of the rotor piston pneumatic engines permits to solve the following practical problems:

- verification of the exergy balance of the pneumatic engine for the compliance with the second law of thermodynamics;

- comparison of specific consumptions of the compressed working agent and energy;

- efficiency estimation of the pneumatic engine;

- estimation of primary and secondary energy resources.

Thus, the efficiency estimation of the rotor piston pneumatic engines using the exergy method is urgent and perspective.

The aim of the present research is to estimate the efficiency of the energy conversion of the compressed air in the working cylinder of the rotary piston pneumatic engines using the exergy method of thermodynamic analysis.

\section{RESEARCH METHODS}

The analysis of the energy efficiency of the rotary piston pneumatic engines is performed using the method of mathematical modeling based on the results of the physical modeling. Thus, the experimental characteristics of the pneumatic engine operation at different operational modes are the basis for the thermodynamic analysis and determination of the engine exergy efficiency.

Since the rotary piston pneumatic engines are expansion motors, the exergy of the air flow is determined by the work, which can be performed by the unit of mass of this flow with the initial parameters $P_{s}, T_{s}, h_{s}, S_{s}, v_{s}$ at the interaction with the environment with parameters $P_{0}, T_{0}$, $h_{0}, S_{0}, v_{0}$.

Figure 2 shows the theoretical diagram of the energy flows upon the expansion of the compressed air in the rotary piston pneumatic engine. The characteristic feature of this process is the exergy conversion, which is connected with the excess pressure of the working agent, into the exergy connected with cooling.

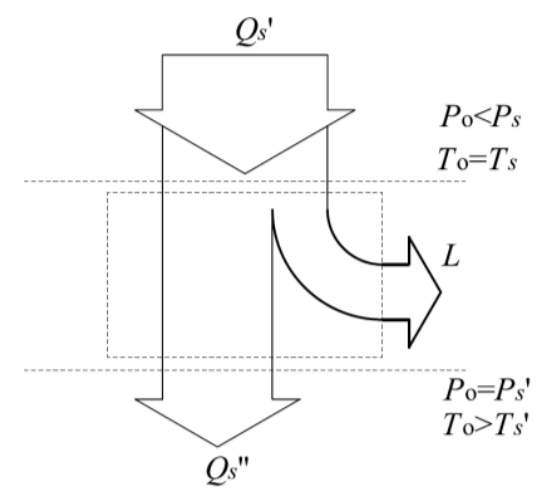

Fig. 2. Theoretical diagram of energy flows upon the expansion of the working agent

According to $[1-7,39,40]$, the specific exergy and anergy of the compressed air flow that passes through the pneumatic engine can be determined as follows:

$$
\begin{aligned}
& e=h_{s}-h_{0}-T_{0}\left(S_{s}-S_{0}\right), \\
& a=h_{0}+T_{0}\left(S_{s}-S_{0}\right),
\end{aligned}
$$

where $h_{s}, h_{0}$ is the specific air enthalpy, which corresponds to the air parameters in the inlet receiver of the pneumatic engine and the environmental parameters, correspondingly; $S_{s}$, $S_{0}$ is the specific air entropy, which corresponds to the air parameters in the inlet receiver of the pneumatic engine and the environment parameters; $T_{0}$ is the environmental temperature, or in the differential form:

$$
d e=d h-T_{0} d S,
$$

where

$$
d h=c_{p} d T-\left[T\left(\frac{\partial v}{\partial T}\right)_{p}-v\right] d P,
$$




$$
d S=\frac{c_{v}}{T}\left(\frac{\partial T}{\partial P}\right)_{v} d P+\frac{c_{p}}{T}\left(\frac{\partial T}{\partial v}\right)_{p} d v
$$

Inserting equations (4) and (5) into equation (3) and replacing value $c_{v}$ for $c_{p}$, we shall get a finite equation of determination the exergy of the air flow in the differential form:

$$
d e=\frac{T-T_{0}}{T}\left[c_{p} d T-T\left(\frac{\partial v}{\partial T}\right)_{p} d P\right]+v d p
$$

Having the hourly value of consumption the compressed air, which passes through the rotary piston pneumatic engine, we can determine the flow exergy [1]:

$$
E_{x}=\frac{G_{a i r} e}{3600}
$$

where $G_{a i r}$ is the real general hourly consumption of the compressed air.

The economic factor, which characterizes the perfection of organization of the energy conversion in the rotary piston pneumatic engine, is the exergy coefficient of efficiency. Correspondingly, having the experimentally obtained values of efficient power $N_{e}$ of the rotary piston pneumatic engine and the value of the exergy of the compressed air flow, it is possible to determine the exergy coefficient of the useful effect [39]:

$$
\eta_{e}^{e_{x}}=\frac{N_{e}}{E_{x}}
$$

The redistribution of the flows of energy (Fig. 1) and, particularly, the value of the exergy efficiency of the rotary piston pneumatic engine are substantially affected by the internal and external losses. The internal losses of the pheumatic engine the mechanic (friction in the engine elements) and gasdynamic (hydraulic resistance of the pipe lines, air inlet and outlet systems, air wiredrawing up to the working pressure in the inlet receiver) can be considered. The compressed air escape through sealing-in, can be above all referred to the external losses. On this basis, the determination of the effect of the operational parameters of the rotary piston pneumatic engine on the change in the values of the internal and external losses is the major task.

\section{THE RESEARCH RESULTS}

The rotary piston pneumatic engine differs from those serially produced pneumatic engines with regard to the motion mechanisms constructions and a gas exchange. It is one of the engineering test samples. Accordingly, the application of experimental data to estimate the efficiency using the exergy method will enable to appreciate a real situation in the context of the compressed air energy conversion and will make it possible to determine the exergy flow value at the outlet (the loss value). The exergy method application without the experimental data can give only a general theoretical picture of the exergy flow and anergy distribution, it cannot allow taking into account and analyze the effect of the operational parameters on the energy conversion process. Therefore, the use of this method without the experimental data can be used only in the limited form, e.g., for the initial evaluation at the design stage.

To analyze the energy conversion efficiency of the compressed air in the working cylinder of the rotary piston pneumatic engine using the exergy method, the experimental studies were performed, and the operational characteristics of the work were obtained.

The energy conversion efficiency of the compressed air in the rotor piston pneumatic engine is mostly affected by such parameters as the working air pressure in the inlet receiver $P_{s}$, as well as the engine rpm $n$. The experimental studies were performed for the range of the operational pressure in the inlet receiver of $0.4 \ldots 0.8 \mathrm{MPa}$ and $400 \ldots 1400 \mathrm{rpm}$. At the present stage of the experimental studies, the tests of the rotary piston pneumatic engine were carried out without changing the degree of filling (the regulating cam was in a neutral position) and the engine speed (1400 rpm) were accepted as nominal (maximum). At the beginning of the experimental studies of the rotary piston pneumatic engine, the errors were evaluated of all the measuring instruments and the bench, on the whole. As a result of the verification, the maximum instrumental error was up to $5 \%$, which is quite reasonable for the experimental study.

Figures 3 and 4 show the experimental results of changing the cyclic efficient work $L_{e}$ and specific efficient work $l_{e}$ of the rotary piston pneumatic engine with respect to rotations $n$ and the working pressure in the inlet receiver $P_{s}$. 


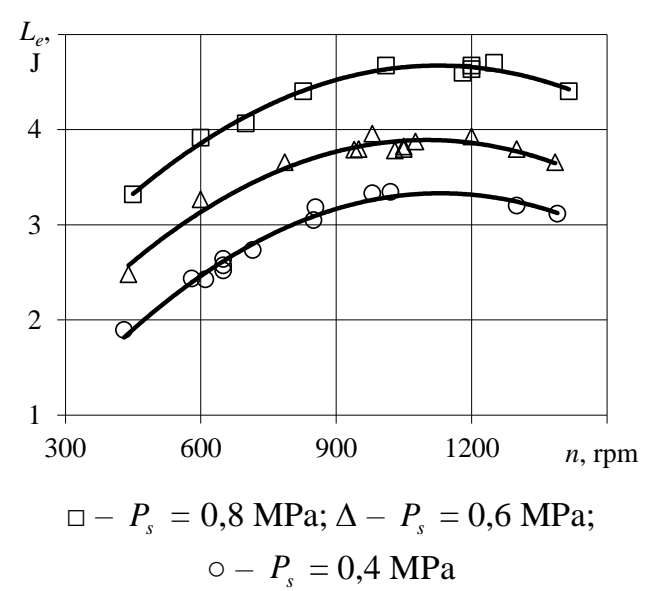

Fig. 3. Change in cyclic efficient work $L_{e}$ of rotary piston pneumatic engine with respect to speed $n$ and pressure in the inlet receiver $P_{s}$.

The specific efficient work characterizes the amount of the useful yield obtained in the pneumatic engine per $1 \mathrm{~kg}$ of the supplied air. Thus, the maximum values of $l_{e}$ throughout the entire range of the pressure change in the inlet receiver of the pneumatic engine are in the range of $800 \ldots 1000 \mathrm{rpm}$ and are $57 \ldots 72 \mathrm{~kJ} / \mathrm{kg}$. The minima of $l_{e}=f\left(P_{s}, n\right)$ are at maximum and minimum values of the operational parameters. So, the range of rotations in the rotary piston pneumatic engines that corresponds to $55 . .70 \%$ from the nominal, is the most optimal from the viewpoint of the specific efficient work.

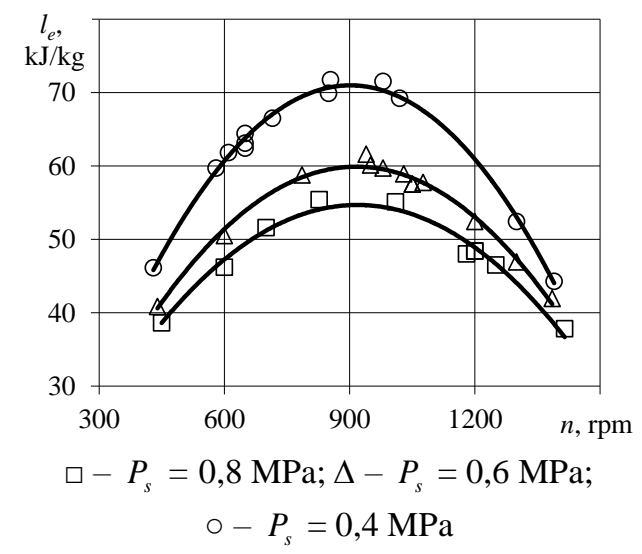

Fig. 4. Change in specific efficient work $l_{e}$ of rotary piston pneumatic engine depending on $n$ and $P_{s}$

The result obtained can be explained by the following:

- the test pneumatic engine is not a seriallyproduced article and, it was designed for the work according to the speed characteristics;
- the ratio between the compressed air leaks and gasdynamic losses.

At minimum speeds of the pneumatic engine, the compressed air leaks affect substantially the energy conversion efficiency. At minimum rotations, the leaks are maximum, and with an increase in rotations they decrease. However, the gasdynamic losses, on the contrary, are the least at minimum rotations and are the highest at maximum.

Respectively, the mode of the maximum efficient work is that, at which the total losses in the process of the compressed air energy conversion into the useful yield become minimum, which motivates the character of the change in the curve of the efficient work.

To determine the exergy efficiency of the rotary piston pneumatic engine it is necessary to define the flow exergy of the compressed air, which is supplied to the engine. Having the air parameters at the inlet and outlet from the pneumatic engine, as well as the hourly air consumption for different modes of the work (Fig. 5), the exergy change in the compressed air flow $E_{x}$ can be determined.

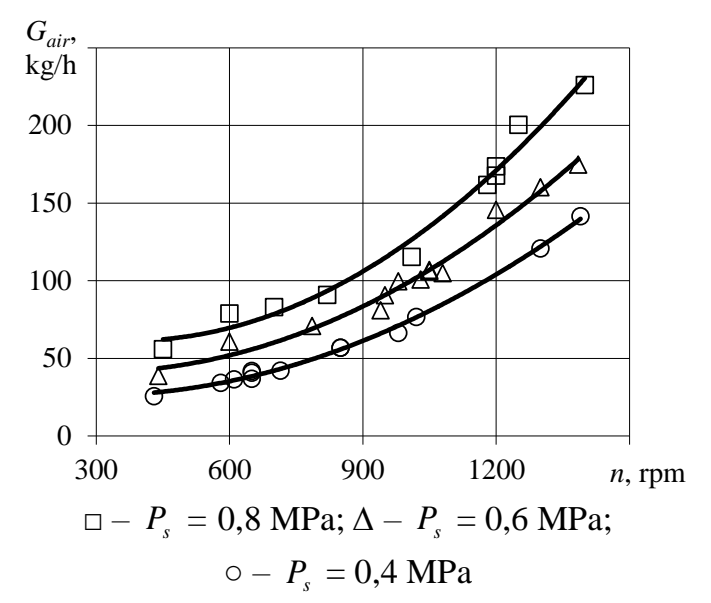

Fig. 5. Hourly air consumption of rotary piston pneumatic engine without air preheating at the inlet and adjusting the degree of filling

Figure 6 shows the change in the exergy of the compressed air flow with regard to the rotations and pressure in the inlet receiver. If we divide the efficient power of the rotary piston pneumatic engine into supplied exergy of the compressed air flow, we shall obtain the exergy efficiency, whose change depending on $P_{s}$ and $n$ is illustrated in Fig. 7. 


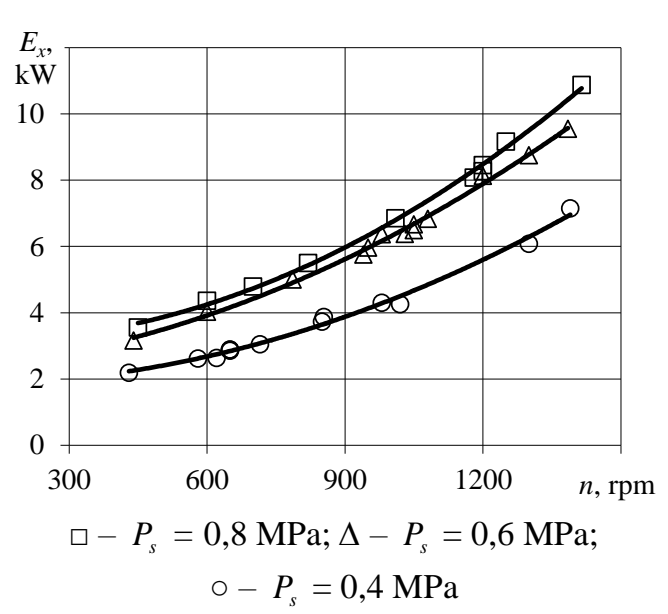

Fig. 6. Change in the compressed air flow exergy $E_{x}$ depending on rotary piston pneumatic engine $n$ and $P_{s}$

The same as for the specific efficient work, the low values of the exergy efficiency at low rotations of the pneumatic engine can be explained by the considerable compressed air leaks, whereas the efficiency decrease in the range of high rotations (over $85 \%$ of the nominal) - by the increase in the gasdynamic and mechanical losses.

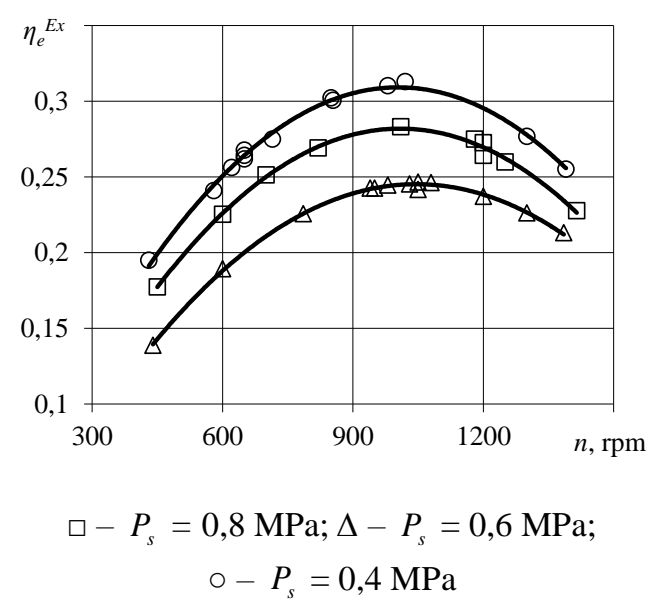

Fig. 7. Change in specific efficiency of $\eta_{e}^{E_{x}}$ of rotary piston pneumatic engine depending on $n$ and $P_{s}$

Maximum values of the exergy efficiency of the rotary piston pneumatic engine for all values of $P_{s}$ are also in the range of $55 \ldots 70 \%$ of the nominal values of the rotations. Here, the maximum value of the exergy efficiency is relevant to the minimum operation pressure of the compressed air in the inlet receiver of 0.4 $\mathrm{MPa}$, and in the absence of regulation of the degree of filling it is 0.31 . The twofold increase in the pressure in the inlet receiver decreases the exergy efficiency by $8.2 \%$ at a simultaneous growth in the efficient power by $46 \%$.

It is noteworthy that the exergy efficiency unlike, e.g., the thermal efficiency of an ideal cycle, does not show the extent of the TS achievement of a theoretical ideal, but allows performing a qualitative assessment of the TS useful yield per unit of the consumed energy under the definite preconditions.

The exergy efficiency value as well depends directly on the choice of the objective function. In our case, during determination of the exergy efficiency by the objective function, the obtainment of the mechanical operation (adiabatic detander) was chosen. In this case, the refrigerant production in the process of expansion was not considered (in fact, the engine produced refrigerant was balanced by heat supply from the environment). The introduction of the TS deep utilization of the refrigerant (the energy supply from the unit being cooled in the form of heat) will make it possible to considerably enhance the value of the exergy efficiency.

The available experimental data on changing parameters of the working agent in the expansion process, it is possible to estimate the value of particular internal losses (without considering the air leaks) for a certain mode of the pneumatic engine operation, e.g., for the mode of the maximum efficient operation. In order to do this, let us plot a scale band of the anergy-exergy diagram of the energy conversion (the Grossman diagram) in the form of specific exergy and anergy flows (Fig. 8).

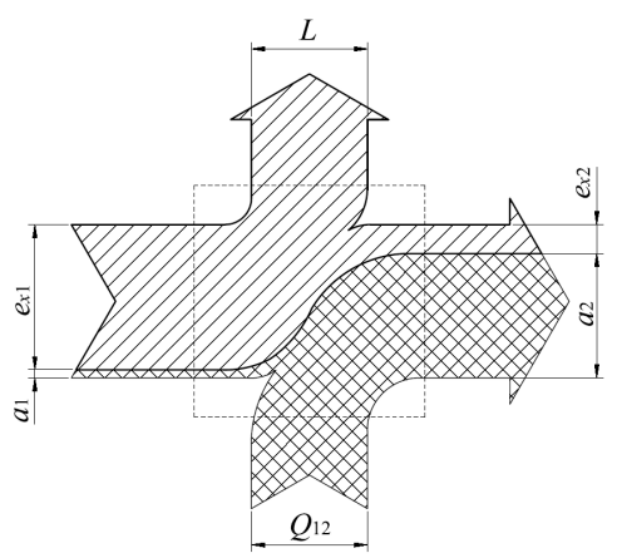

Fig. 8. Scheme of energy flows of the compressed air expansion process in the working cylinder of rotary piston pneumatic engine 
The diagram shows that the energy flow in the TS inlet consists of exergy $e_{x 1}$ and anergy $a_{1}$, and at the outlet - from $e_{x 2}$ and $a_{2}$.

Here, the exergy substantial part $e_{x 1}$ turns into the useful yield $L$, and the other part passes into exergy $e_{x 2}$ of the wasted air. Heat $Q_{12}$ serves to compensate for the compressed air anergy to maintain the balance according to the first law of thermodynamics. Upon that, the second law of thermodynamics was displayed in the exergy flow decrease. The source of exergy $e_{x 1}$ is the compressed air resulted from the excess pressure Ps and having a potential energy reserve. In the process of expansion, the potential energy turns into mechanical energy with pressure $P_{s}$ and temperature $T_{s}$ having a tendency to $P_{0}$ and $T_{0}$, i.e., to reach a thermodynamic equilibrium with the environmental medium. In the present example, exergy $e_{x 2}$ is $20 \%$ of flow $e_{x 1}$ and, in fact, is a value of the internal losses in the cycle. The remaining part of the losses, which decreases the total energy efficiency, falls at the external losses. Hence, one major task is to decrease these TS constituing losses.

We can emphasize two main directions of enhancing the efficiency of conversion of the compressed air in the rotary piston pneumatic engines:

- updating of design defects (e.g., improvement of the sealing arrangements to reduce the leaks, upgrading lubrication of rubbing parts of the pneumatic engine, reducing the outlet system resistance);

- optimization of the operation process (e.g., ensuring the control over the degree of filling the working cylinder of the pneumatic engine for each exploitation mode, selection of an optimal ratio of parameters $P_{s}$ and $n$, introduction the energy unit for the refrigerant utilization into the scheme).

\section{CONCLUSIONS}

The thermodynamic analysis of the compressed air energy conversion of the rotary piston pneumatic engines that was carried out using the exergy method enabled to estimate the value and distribution of the primary and secondary energy flows, to determine the efficiency of the pneumatic engine in terms of generation the mechanical energy, which was the objective function, as well as to establish the effect of the operational parameters on the efficiency of the energy conversion.

The physical and mathematical modeling of various modes of the work of the rotary piston pneumatic engine allowed us to determine the quantity of the exergy supplied by the compressed air flow, which is in the range of $2.2 \ldots 11.4 \mathrm{~kW}$. Upon that, the specific unemployed energy at the outlet from the pneumatic engine is $20 \%$ of the supplied exergy at the inlet. Also, the unused potential remains in the TS, which is the conversed exergy of the excess pressure of the compressed air in the form of low temperature of the working agent (a cooling effect). The use of the low temperature of the spent air will make it possible to substantially enhance the efficiency of the energy conversion of the entire facility.

It was determined that the optimal range of the rotary piston engines speed to achieve the maximum values of the specific efficient work and exergy efficiency is $55 \ldots 70 \%$ of the nominal value. With respect to the inlet receiver pressure of the rotary piston pneumatic engine, the maximum values of the specific efficient work are $57 \ldots 72 \mathrm{~kJ} / \mathrm{kg}$, and maximum values of the exergy efficiency is $0.29 \ldots 0.31$. The decreasing in efficiency of the energy conversion at the rpm low modes results from the compressed air enhanced leaks through the sealing arrangements. At the revolution modes close to the nominal values, the decrease in the efficiency of the pneumatic engine is observed with an increase in the gasdynamic and mechanical losses.

It was established that an increase in the working pressure in the inlet receiver of the rotary piston pneumatic engine somewhat decreases the exergy efficiency. Thus, with a twofold increase in the working pressure, the increase in the efficient power of the pneumatic engine occurs by $46 \%$ with the exergy efficiency being decreased by $8.2 \%$.

Based on the results obtained, promising are further deeper theoretical and experimental studies of internal and external losses in the rotary piston pneumatic engines at the operation modes close to minimum and nominal speeds of rotation. In addition, the study of the working pressure effect of the pneumatic engine on its efficient characteristics is of practical interest. 


\section{References}

[1] Brodyanskij V.M. Eksergeticheskij metod termodinamicheskogo analiza. [The exergy method of thermodynamic analysis]. Moscow, Energiya, Publ., 1973. 296 p.

[2] Brodyansky VM, Fratscher V., Mikhalek K. Exergetic method and its applications. [Exergetic method and its applications]. Moscow, Energoatomizdat, Publ., 1988. 288 p.

[3] Gohshtejn D.P. Sovremennye metody termodinamicheskogo analiza energeticheskih ustanovok. [Modern methods of thermodynamic analysis of power plants]. Moscow, Energiya, Publ., 1969. 255 p.

[4] Shargut Ya., Petela R. Eksergiya. [Exergia]. Moscow, Energiya, Publ., 1968. 386 p.

[5] J. A. McGovern. Exergy analysis - a different perspective on energy part 1: the concept of exergy. Proceedings of the Institutionof Mechanical Engineers Part A: Journal of Power and Energy, 1990, vol. 204, no. 4, pp. 253-262.

[6] J. A. McGovern. Exergy analysis - a different perspective on energy, part 2: rational efficiency and some examples of exergy analysis. Proceedings of the Institution of Mechanical Engineers, Part A: Journal of Power and Energy, 1990, vol. 204, no.4,pp. 263-268.

[7] Stecco S.S., Manfrida G. Exergy analysis of compression and expansion processes. Energy, 1986, vol. 11, no. 6, pp. 573-577.

[8] Soteris A. Kalogirou, Sotirios Karellas, Viorel Badescu, Konstantinos Braimakis Exergy analysis on solar thermal systems: A better understanding of their sustainability Renewable Energy, 2016, № 85, pp. 1328-1333

[9] Jafarkazemi F., Ahmadifard E. Energetic and exergetic evaluation of flat plate solar collectors, Renew. Energy, 2013, 56 pp. 55-63.

[10] Ge Z., Wang H., Wang H., Zhang S., Guan X., Exergy analysis of flat plate solar collectors. Entropy, 2014, 16 (5), pp. 2549-2567.

[11] Bahrehmand D., Ameri M. Energy and exergy analysis of different solar air collector systems with natural convection, Renew. Energy, 2015, 74, pp. 357-368.

[12] Assari M.R., Tabrizi H.B., Jafari I., Najafpour E. An energy and exergy analysis of water and air with different passage in a solar collector, Energy Sources Part A Recovery Util. Environ. Eff., 2014, 36 (7), pp. 747-754.

[13] Joong Yong Yi, Kyung Min Kim, Jongjun Lee, Mun Sei Oh. Exergy Analysis for Utilizing Latent Energy of Thermal Energy Storage System in District Heating. Energies, 2019, 12, 1391 pp. 113. doi:10.3390/en12071391

[14] Rezaie B., Reddy B.V., Rosen M.A. Exergy Analysis of Thermal Energy Storage in a District
Energy Application. Renew. Energy, 2015, 74, pp. 848-854.

[15] Reddy A.V., Kumar T.S., Kumar D.K.T., Dinesh B., Santosh Y.V.S.S. Energy and exergy analysis of I.C. engines. The International Journal of Engineering and Science, 2014, vol. 3, no. 5, pp. 7-26.

[16] Ameri M., Kiaahmadi F., Khanaki M., Nazoktabar M. Energy and exergy analyses of a spark-ignition engine. International Journal of Exergy, 2010, vol. 7, no. 5, pp. 547-563.

[17] Sayin C., Hosoz M., Canakci M., Kilicaslan I. Energy and exergy analyses of a gasoline engine. International Journal of Energy Research, 2007, vol. 31, no. 3, pp. 259-273.

[18]Caton J.A. "Exergy destruction during the combustion process as functions of operating and design parameters for a sparkignition engine," International Journal of Energy Research, 2012, vol. 36, no. 3, pp. 368-384.

[19] Jafarmadar S., Tasoujiazar R., Jalilpour B., Exergy analysis in a low heat rejection IDI diesel engine by three dimensional modeling. International Journal of Energy Research, 2014, vol. 38, no. 6, pp. 791-803.

[20] Ibrahim Thamer Nazzal1, Raaid Rashad Jassem AlDoury. Exergy and Energy Analysis of Diesel Engine Fuelled with Diesel and Diesel - Corn Oil Blends. Journal of Advanced Research in Fluid Mechanics and Thermal Sciences, 2019, № 63, Issue 1, pp. 92-106.

[21] Nabi M.N., Rasul M.G. Influence of second generation biodiesel on engine performance, emissions, energy and exergy parameters. Energy Conversion and Management, 2018, № 169, pp. 326-333.

[22] Meisami Farshad, Hossein Ajam. Energy, exergy and economic analysis of a Diesel engine fueled with castor oil biodiesel. International Journal of Engine Research, 2015, 16, no. 5, pp. 691-702.

[23] Hoseinpour Marziyeh, Hassan Sadrnia, Mohammad Tabasizadeh, Barat Ghobadian. Energy and exergy analyses of a diesel engine fueled with diesel, biodiesel-diesel blend and gasoline fumigation. Energy, 2017, 141, pp. 2408-2420.

[24] Şanli Bengi Gözmen, Erinç Uludamar. Energy and exergy analysis of a diesel engine fuelled with diesel and biodiesel fuels at various engine speeds. Energy Sources, Part A: Recovery, Utilization, and Environmental Effects, 2019, pp.1-15.

[25] Bahar Sayin Kul, Ali Kahraman. Energy and Exergy Analyses of a Diesel Engine Fuelled with Biodiesel-Diesel Blends Containing 5\% Bioethanol. Entropy, 2016, 18, 387, pp.1-18. doi:10.3390/e18110387 
[26] Haydar Aras, Ozgur Balli. Exergoeconomic analysis of a combined heat and power system with the micro gas turbine (MGTCHP). Energy exploration and exploitation, 2008, Volume 26, Number 1, pp. 53-70.

[27] Ebadi M.J., Gorji-Bandpy M. Exergetic analysis of gas turbine plants. International Journal of Exergy, 2005, 2, pp. 285-290.

[28] Kwak H-Y., Kim D-J., Jeon J-S. Exergetic and thermoeconomic analyses of power plants. Energy, 2003, 28, pp. 343-360.

[29] Sandeep Kumar Kamboj, Munawar Nawab Karimi. Exergy Analysis of Internal Combustion Engine Based Cooling Cycle. Int. J. of Thermal \& Environmental Engineering, 2018, Volume 16, No. 2, pp. 113-118.

[30] Michel Feidt, Monica Costea. Energy and Exergy Analysis and Optimization of Combined Heat and Power Systems. Comparison of Various Systems. Energies, 2012, 5, pp. 3701-3722. doi:10.3390/en5093701

[31] Nieminen, J., Dincer, I. Comparative exergy analyses of gasoline and hydrogen fuelled ICEs. Int.J. Hydrogen Energy, 2010, 35, pp. 5124-5132.

[32] Barelli, L., Bidini, G., Gallorini, F., Ottaviano, A. An energetic-Exergetic comparison between PEMFC and SOFC-based micro-CHP systems. Int. J. Hydrogen Energy, 2011, 36, pp. 32063214. Xu Huanxiang, Yu Xiaoli, Wang Lei, Fang Yidong, Fan Zhipeng, Dou Wenbo, Li Daofei. Exergy analysis on compressed air engine. Transactions of the Chinese Society of Agricultural Engineering, 2016, Volume 32, Supplement 1, pp. 42-49.

[33] McGovern J.A., Harte S. An exergy method for compressor performance analysisMéthode exergétique d'analyse des performances des compresseurs. International Journal of Refrigeration, 1995, Volume 18, Issue 6, pp. 421433.

\section{Information about authors.}

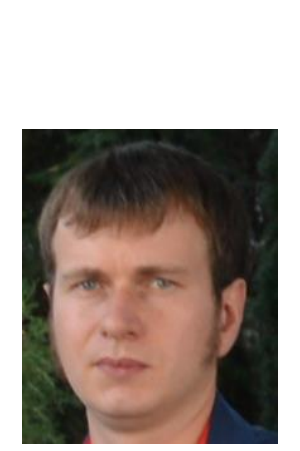

\author{
Mytrofanov \\ Oleksandr \\ Sergeyevich \\ $\mathrm{PhD}$, Associate Professor of \\ Department of Internal \\ Combustion Engines, Plants \\ and Operation \\ Research interests: engines of \\ unconventional schemes, \\ alternative fuels, waste energy \\ utilization. \\ E-mail:
}

mitrofanov.al.ser@gmail.com

ORCID: 0000-0003-34605369
[34] Iodice, P.; Langella, G.; Amoresano, A. Modeling and energetic-exergetic evaluation of a novel screw expander based direct steam generation solar system. Appl. Therm. Eng. 2019, 155, pp. 82-95.

[35] Fancong Zeng, Jinli Xu. Study on exergy analysis of a compressed air engine. Thermal Science, 2018, vol. 22, № 3, pp. 1179-1191.

[36] Morosuk T., Tsatsaronis G. Advanced exergetic evaluation of refrigeration machines using different working fluids. Energy, 2009, vol. 34, no. 12, pp. 2248-2258.

[37] Alison Subiantoro, Kin Keong Wong, Kim Tiow Ooi. Exergy Analysis of the Revolving Vane Compressed Air Engine. International Journal of Rotating Machinery, 2016, pp. 1-8. http://dx.doi.org/10.1155/2016/5018467

[38] Hao-jie Tang, Shu-xi Zheng, Yu-tao Yang, Chao Wang, You-xin Zhao, Su-yan He. Energy and Exergy Analysis of a Refrigeration System with Vapor Injection Using Reciprocating Piston Compressor. Advances in Engineering Research, 2016, volume 94, pp. 436-439.

[39] Voronkov O.I. Metodologiya organizaciyi robochogo procesu pnevmodviguna kombinovanoyi energetichnoyi ustanovki miskogo avtomobilya. Diss. dokt. tehn. nauk [Methodology for organizing the working process of a pneumatic engine of a combined power plant of a city car. Dr. technical sci. diss.]. Kharkiv, 2017. 393 p.

[40] Abramchuk F.I., Harchenko A.I., Voronkov A.I., Nikitchenko I.N. Ispol'zovanie eksergeticheskogo metoda pri termodinamicheskom analize gazovyh processov $v$ teplovyh mashinah [The use of the exergy method in thermodynamic analysis of gas processes in heat engines]. Vestnik HNADU HNADU Bulletin, 2011, no. 53, pp. 32-44.

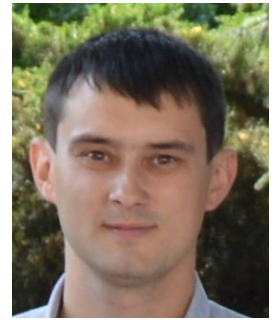

\section{Proskurin Yuryevich}

$\mathrm{PhD}$, Associate Professor of Department of Internal Combustion Engines, Plants and Operation

Research interests: engines of unconventional schemes, alternative fuels, waste energy utilization.

E-mail:

arkadii.proskurin@nuos.edu.ua ORCID: 0000-0002-52256767 